\title{
Technology licensing in China
}

Wang, Yuandi; Li-Ying, Jason; Chen, Jin; Lu, Zheng

\section{Published in:}

Science and Public Policy

Link to article, DOI:

10.1093/scipol/scu037

Publication date:

2015

\section{Document Version}

Publisher's PDF, also known as Version of record

Link back to DTU Orbit

\section{Citation (APA):}

Wang, Y., Li-Ying, J., Chen, J., \& Lu, Z. (2015). Technology licensing in China. Science and Public Policy, 42, 293-299. https://doi.org/10.1093/scipol/scu037

\section{General rights}

Copyright and moral rights for the publications made accessible in the public portal are retained by the authors and/or other copyright owners and it is a condition of accessing publications that users recognise and abide by the legal requirements associated with these rights.

- Users may download and print one copy of any publication from the public portal for the purpose of private study or research.

- You may not further distribute the material or use it for any profit-making activity or commercial gain

- You may freely distribute the URL identifying the publication in the public portal

If you believe that this document breaches copyright please contact us providing details, and we will remove access to the work immediately and investigate your claim 


\title{
Technology licensing in China
}

\author{
Yuandi Wang ${ }^{1}$, Jason Li-Ying ${ }^{2, *}$, Jin $\mathrm{Chen}^{3}$ and Zheng $\mathrm{Lu}^{4}$ \\ ${ }^{1}$ Business School of Sichuan University, Sichuan University, No. 29, Wangjiang Road, Chengdu, \\ 610064, Sichuan, China. \\ ${ }^{2}$ DTU Management Engineering, Technical University of Denmark, DK-2800 Kgs. Lyngby, \\ Denmark. \\ ${ }^{3}$ Department of Innovation, Entrepreneurship and Strategy, School of Economics and Management, \\ Tsinghua University, Qinqhuayuan 1, Beijing, 100084, China. \\ ${ }^{4}$ School of Economics, Sichuan University, No. 29, Wangjiang Road, Chengdu, 610064, Sichuan, \\ China. \\ *Corresponding author. Email: yinli@dtu.dk.
}

\begin{abstract}
We explore the landscape of technology licensing among Chinese entities in the period 2000-12, using a unique database on technological licensing from the State Intellectual Property Office of China. We find that: first, among Chinese licensee organizations, firms have dominated in terms of the number of licensed technologies; second, the geographical distribution of licensed technologies among the provinces has gradually reached a new quantitative balance; third, utility models are the most popular technologies to be licensed and the majority of technology licensing in China has been between Chinese entities, and most transactions have been local within provinces; and finally, Chinese firms have gradually in-licensed newer and newer technologies, but the technologies in-licensed from foreign sources are by no means state-ofthe-art. We make several suggestions for innovation policy-making and for directions for future research.
\end{abstract}

Keywords: technology licensing; innovation; patents; China.

\section{Introduction}

Technological innovation is an important driving force for regional and national economic growth and competitive advantage. That is why China is determined to upgrade its economy from labor-intensive manufacturing to more knowledge-intensive industries led by innovation-oriented firms (Altenburg et al. 2008). The overall trend of patenting by Chinese firms has been explored in the literature (Huang 2010). Since China joined the World Trade Organization in 2001, it has nurtured a policy which is clearly intended to make it an 'innovation-oriented' country by 2020 and a 'leading science power' by 2050 (Chen and Li-Hua 2011). However, the inefficiency and ineffectiveness of Chinese industrial R\&D in the 1980s and 1990s has left the country lagging behind other industrialized countries. Thus, learning from external technology sources through an effective technology market has been promoted as a primary means to overcome technological deficiencies at a national level
(Sun and Du 2010). Technology transfer has been one of the most important vehicles by which firms in China gain access to technological knowledge from developed economies (Chen and Sun 2000). Technology licensing is one of the most important means through which technology transfer is achieved. During the last two decades, patent transactions from developed economies to developing countries have significantly increased (Park and Lippoldt 2004).

It is clear that technology licensing represents a new, external learning mechanism, by which licensees can use in-licensed technologies to strengthen their knowledge base and pursue improved performance (Laursen et al. 2010). However, the large body of literature on external learning through technology licensing mainly focuses on empirical evidence from the USA and Europe (Kollmer and Dowling 2004). The trajectories and patterns of technology licensing in China remain under investigated. This study investigates how Chinese entities have utilized external technology sources through licensing. 


\section{Technology licensing and patents}

'Technology licensing' refers to a license agreement under which a licensee is granted access to a licensor's technologies or patents. A technology license agreement involves two parties with different but related learning processes: the licensor exploits its knowledge externally by means of outward technology licensing, and the licensee needs to internalize in-licensed technologies through an exploitative or exploratory learning process (Cummings and Teng 2003). From a licensee's perspective, especially for firms in developing countries, in-licensing technology can provide firms with strategic assets that are crucial to fill gaps in the competencies needed to achieve competitive advantage in domestic or international markets (Deng 2009).

In order for technologies to be licensed, they need to be systematically codified: typically, the mechanism for this is patents. This is because patents contain reliable information about inventions that are industrially useful and nonobvious to an individual who is knowledgeable in the relevant technical field, establish the ownership of intellectual property rights, and reveal firms' technological portfolio and strategy (Ernst 2003). Thus, in this study, technology licensing refers strictly to the licensing of patents, as prior studies suggest that patent statistics reveal a great deal of knowledge-based innovation in the context of globalization (Grupp and Schmoch 1999).

\section{Technology licensing data in China}

Technology licensing activities are visible, meaning that in most countries one can identify and trace the firms involved in technology licensing. The dataset used for this study was obtained from the State Intellectual Property Office of China (SIPO). Since 2001, SIPO has been authorized by legislation (Regulations on Administration of Record Filing of Technology Licensing) to register technology licensing contracts within three months of them being signed by the licensor and licensee. Each technology transfer record registered at the SIPO contains information on the licensor's name, the licensee's name, the licensing patent number and name, contract number and date, and license type (exclusive or non-exclusive).

License agreements can be signed between individuals and firms in various forms. The licensors or licensees of a licensing agreement could be either Chinese or foreign individuals or firms, but all licensees in the record are Chinese individuals or firms. So far, this dataset only includes licensing agreements that involve patented technology. The complete records for the period 2000-12 are available to the public from the SIPO website (see $<$ http:// www.sipo.gov.cn/> accessed Feb 2013).

In the period 2000-12, there were 27,412 license agreements covering 91,551 transferred patents. These agreements involved 15,959 licensors (including 41,434 individuals) and 18,076 licensees (including 482 individuals). Using data from SIPO, we analyze two main areas of technology licensing in China: patterns regarding licensed technologies, and patterns regarding licensors and licensees and the relationships between them.

\section{Licensed technologies}

\subsection{Overall trends}

The data from SIPO show that the total number of patents in-licensed by Chinese entities (including individuals, firms, universities, research institutes, and other public educational organizations) has increased from 100 in 2000 to 22,697 in 2012 (see Fig. 1). The total number of inlicensing contracts signed by these Chinese entities as licensees has increased from 85 in 2000 to 7,987 in 2012 (see Fig. 2). Both figures show a major increase since 2008 and a significant decrease in 2010. Among all types of licensees, firms had the most significant increase in the number of licensed patents, from 100 in 2000 to 21,750 in 2012, while other types of Chinese entities have experienced a much more modest rate of increase (see Table 1).

In addition, the distribution of technology licensing among the provinces has also evolved according to different patterns. In 2000, only the coastal provinces (Shangdong, Zhejiang, Jiangsu, and Guandong) and Shanghai municipality in Eastern China were active in inward technology licensing; in 2007, the most active provinces were Hebei, Guandong, and Hainan. Interestingly, in 2012, while the coastal provinces and Shanghai were again the most active regions for inlicensing, Heilongjiang and a number of central provinces and municipalities (including Sichuan, Chongqing, Hebei, Henan, An'hui, and others) appeared to be rapidly catching up (see Fig. 3).

\subsection{Which types of technologies?}

Based on the SIPO licensing data, we can trace the origin of licensed patents and check the technical areas to which



Figure 1. Annual number of technologies (patents) in-licensed by Chinese organizations, 2000-12. 
these technologies belong. The findings simply show which types of technologies Chinese licensees have been searching for in the last ten years. Figs 4 and 5, respectively, show the distribution of various types of licensing in terms of absolute value and percentage. We find that design dominated technology licensing in 2000, 2001, and 2004, while inventions prevailed in 2002 and 2003. However, during the last five years, utility models have become the primary licensing type among all types of licensing.

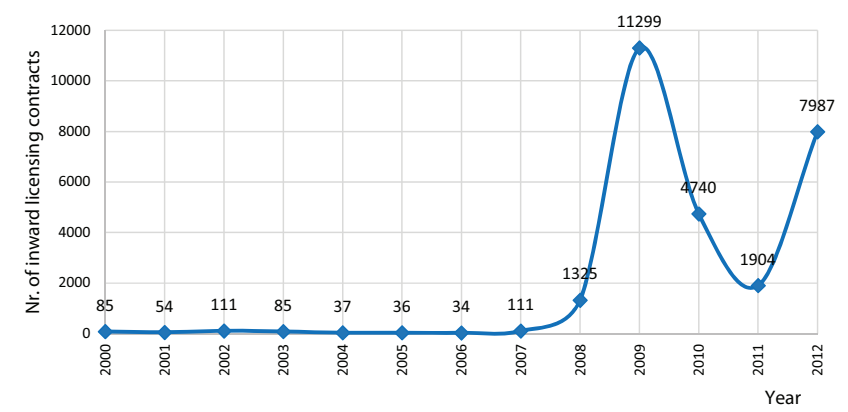

Figure 2. Annual number of technology in-licensing contracts signed by Chinese organizations, 2000-12.

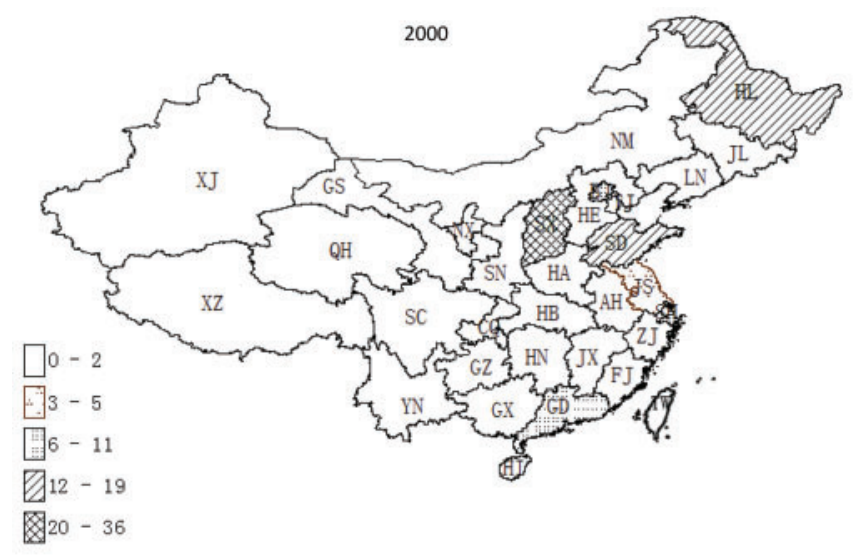

\subsection{Where have technologies come from?}

A Chinese firm or public organization may license technology from domestic or international sources. Since China has been promoting an 'indigenous innovation' policy since 2006, it will be interesting to see whether the source of technology licensing changed after that year. Figs 6 and 7 show the distribution of patents licensed (in absolute value and percentage, respectively) from licensors in China, the USA, Europe, Japan, other Asian countries, and the rest of the world. We find a clear trend that the overall amount of licensing has increased significantly, and Chinese domestic technologies have been the target of the majority of in-licensing agreements since 2007. This is likely the effect of the 'indigenous innovation' policy pursued by the Chinese government since 2006.

\section{Licensors, licensees, and their relationships}

\subsection{Who were the stars?}

The statistics reported above provided an overall picture of the technology licensing landscape in China. Within any

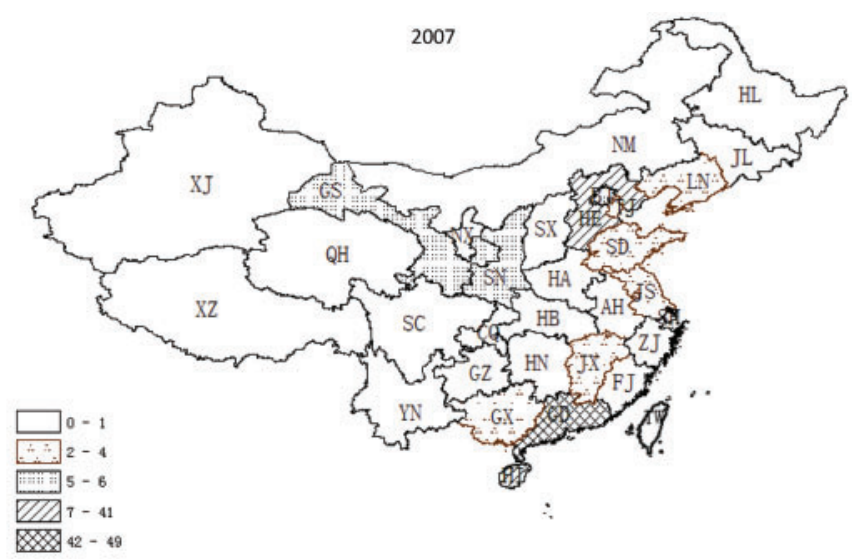

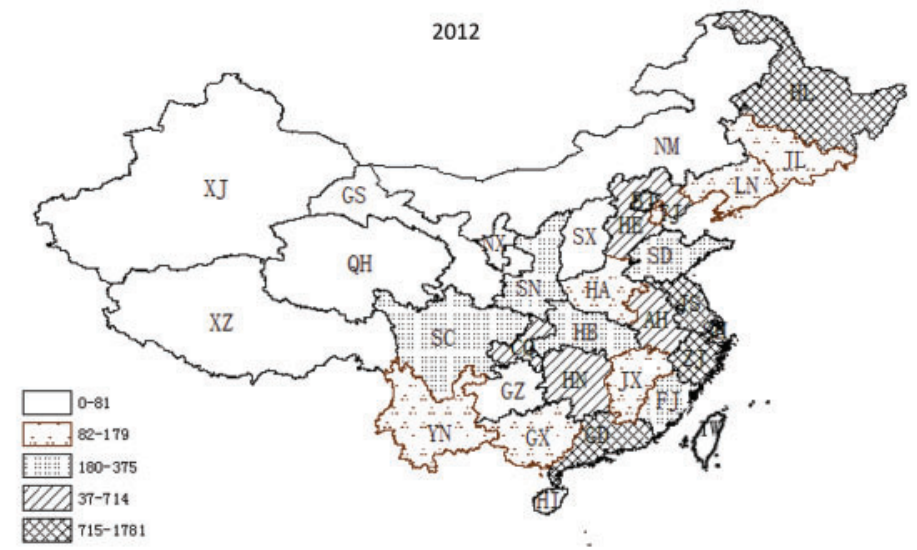

Figure 3. Number of patents in-licensed by Chinese organizations by province (including within-province licensing) in 2000 , 2007, and 2012. 
Table 1. Annual number of technologies (patents) in-licensed by Chinese organizations, 2000-12

\begin{tabular}{|c|c|c|c|c|c|c|c|c|c|c|c|c|c|}
\hline & \multicolumn{13}{|c|}{ Number of patents licensed } \\
\hline Firms & 100 & 58 & 114 & 140 & 247 & 89 & 58 & 193 & 1,693 & 15,383 & 8,067 & 20,423 & 21,750 \\
\hline Educational institutes & 0 & 0 & 0 & 0 & 0 & 0 & 0 & 0 & 0 & 12 & 10 & 43 & 42 \\
\hline Universities and research institutes & 0 & 0 & 1 & 0 & 0 & 26 & 1 & 36 & 62 & 160 & 53 & 227 & 234 \\
\hline
\end{tabular}

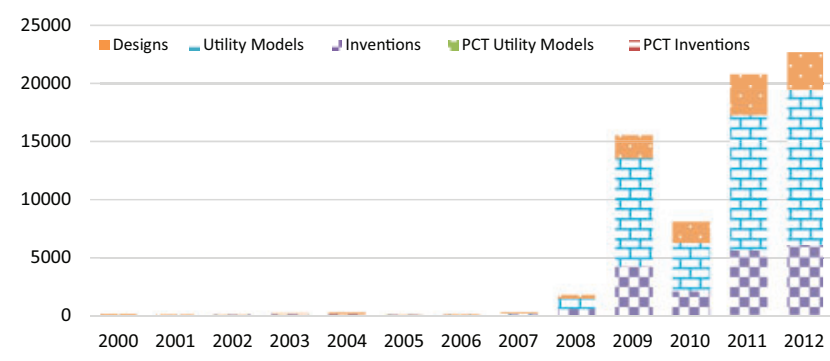

Figure 4. Distribution of in-licensed patents (by absolute value) according to patent types, 2000-12.



Figure 5. Distribution of in-licensed patents (by percentage) according to patent types, 2000-12.

innovation system, there are always organizations that take the lead in pursuing a particular strategic direction and set new frontiers for other organizations to benchmark against. These leaders are those licensors who licensed the most to Chinese firms and those licensees who in-licensed the most external technologies. Fig. 8 shows the top ten licensors that licensed technologies to Chinese entities based on the total number of licensed patents. The champion among licensors (Royal Philips Electronics) licensed 9,916 patents to Chinese licensees in the period 2000-12. Two Chinese universities (South China University of Technology and Zhejiang University) were the leaders among Chinese universities in successful technology transfer through in-licensing.

Fig. 9 shows the top ten Chinese licensees in terms of total number of licensed patents. The champion (Chongqing Heqing Jianyuan Technology Ltd) in-licensed 2,158 patents from various sources. Interestingly, none of

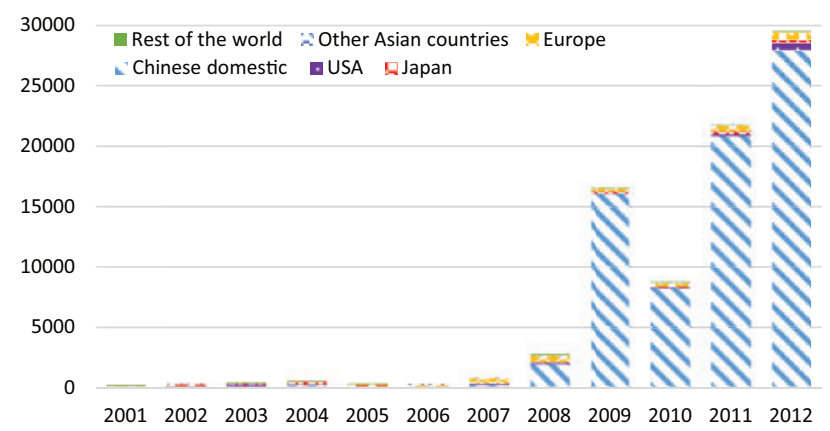

Figure 6. Source of in-licensed technologies (by absolute number), 2000-12.

the top ten licensees are large Chinese corporations, and all of them are in the digital and electronic manufacturing industry.

\subsection{Geographical distance}

Firms search for technologies from various geographical locations. Some prior studies have shown the implications of geographical technology search patterns on firms' innovation performance. Thus, it is important to know where Chinese licensees search for new technologies in which to in-license. Fig. 10 shows the annual distribution of in-licensed patents (in terms of the absolute number) based on the locations of the sources, which can be distinguished into three broad categories: within-province, across provinces, and international. Fig. 11 shows this distribution by percentage. We find that within-province technology licensing has increased significantly since 2007. This finding suggests that the 'indigenous innovation' policy not only promoted more domestic technology transfers, but also made technology search within China much more localized.

\subsection{How old were the technologies?}

Chinese licensees have a choice of licensing mature (old) or state-of-the-art technologies. Some prior studies have shown that mature technologies and new (state-of-the-art) technologies have very different advantages and disadvantages 


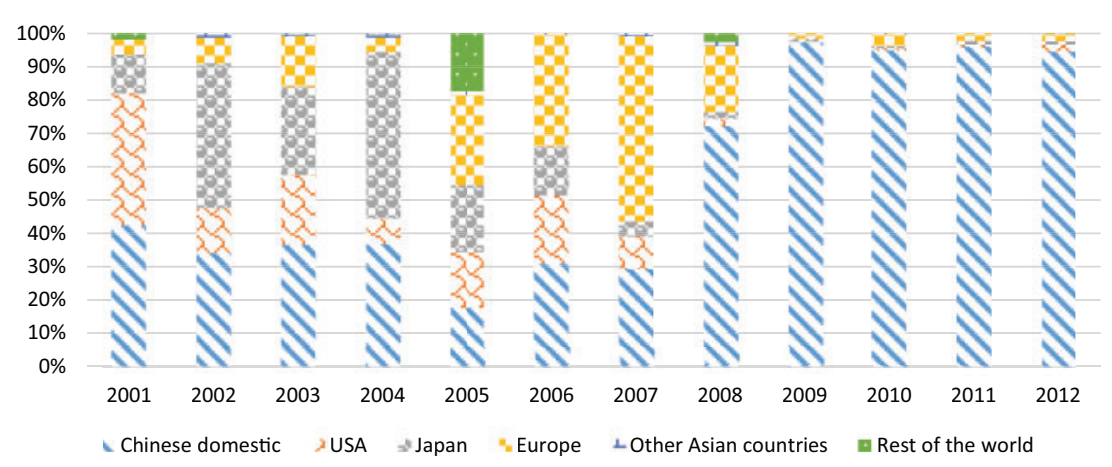

Figure 7. Source of in-licensed technologies (by percentage), 2000-12.

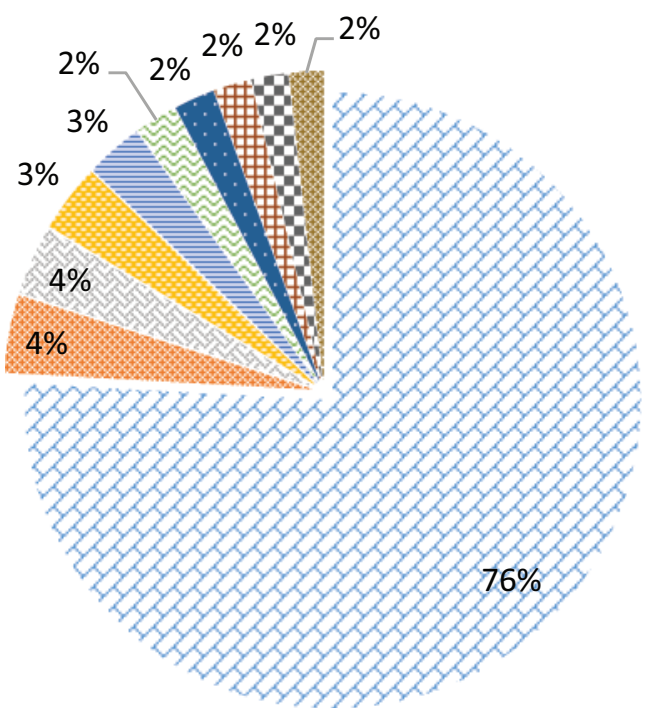

Royal Philips Electronics
DISCOVISON ASSOCIATES
TONGHSU Group
$\equiv$ Midin Flooring
₹PPG Industries (Ohio)
- South China University of Technology
\# Michelin Technology Center
$\square$ Toshiba
Zhejiang University

Figure 8. Top ten licensors (by percentage of total licensed patents), 2000-12.

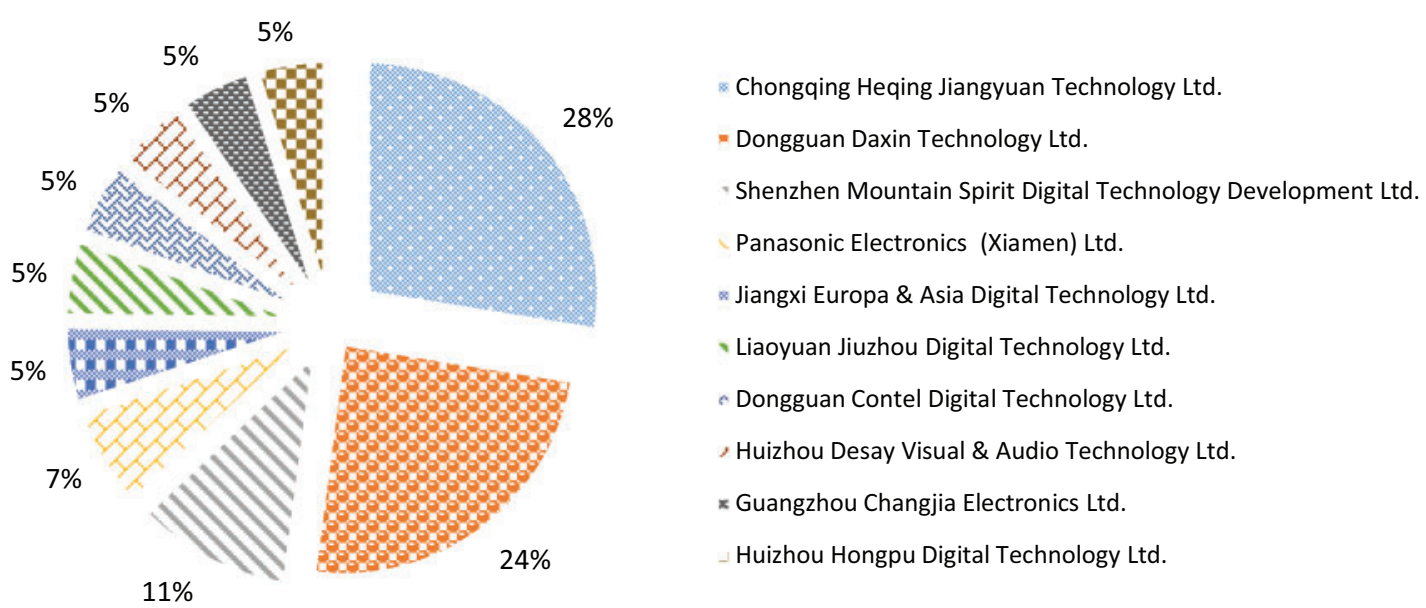

Figure 9. Top ten licensees (by percentage of total in-licensed patents), 2000-12.

for licensees with respect to further innovation. Thus, we are also interested in whether, and to what extent, Chinese organizations are still relying on mature technologies. Fig. 12 shows the average number of years between the granting of a patent and its in-licensing by Chinese licensees. We find that the highest value of about 10 years occurred in the period 2005-7. However, we see a tendency for the average age of in-licensed technologies to fall over the last five years, to an average of about three years. This means that Chinese licensees have gradually shifted their focus to newer technologies. 


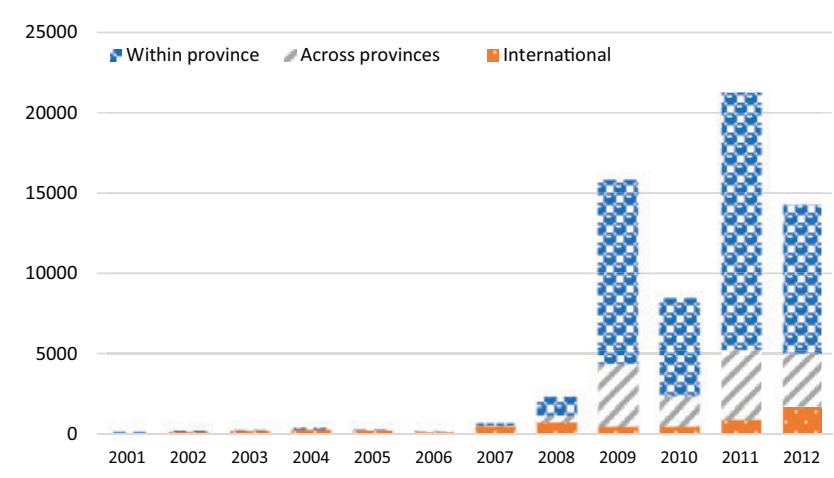

Figure 10. Geographical distribution of in-licensed technology sources, 2001-12.

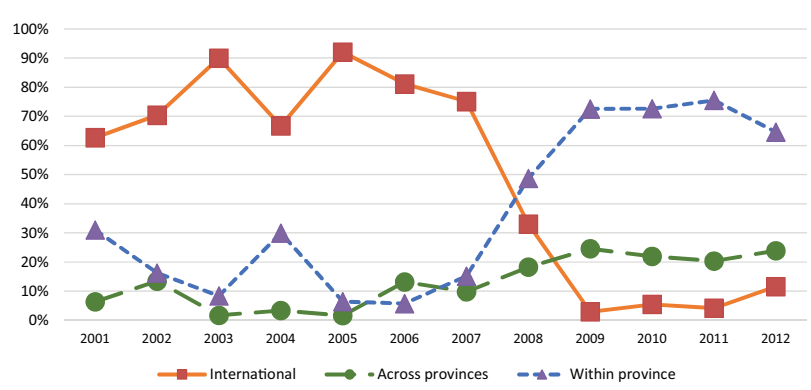

Figure 11. Geographical distribution of in-licensed technology sources (by percentage), 2001-12.

\subsection{Interaction between geographical and temporal distances}

We analyzed above the patterns of geographical distribution of technology sources for Chinese licensees and the age of the licensed technologies. The interaction between these two dimensions is shown in Fig. 13. Interestingly, we find that although the average age of licensed technologies in general has decreased since 2007, this decrease was mainly due to domestic technology licensing (within and across provinces). This suggests that Chinese licensees have not managed to in-source state-of-the-art technologies from international sources.

\section{Conclusions and future research}

This study reveals a number of trends. First, Chinese entities have significantly increased technology licensing activity during the last 12 years, and this increase has accelerated since 2006, when the 'indigenous innovation' policy took effect. Second, among all Chinese licensee organizations, firms have dominated in terms of the numbers of technologies they have licensed. This reflects the fact that firms are playing the most active role in external technology learning and innovating within the Chinese economic and innovation system. Third, the geographical distribution of licensed technologies among provinces in China has gradually reached a new quantitative balance as many Central-Western and Northern provinces are

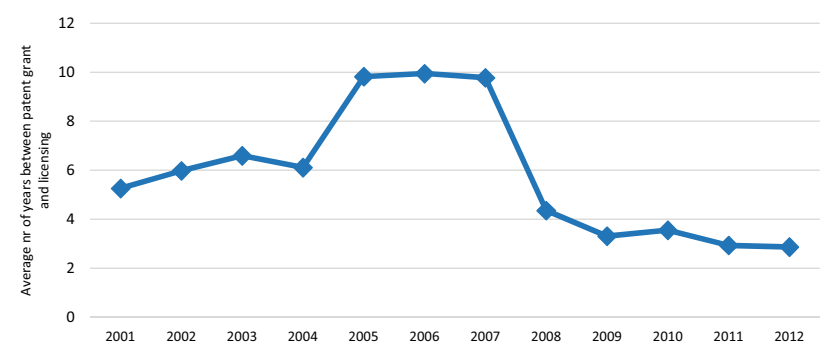

Figure 12. Age of technologies in-licensed by Chinese licensees, 2001-12.



Figure 13. Age vs. geographical sources of technologies inlicensed by Chinese licensees, 2001-12.

catching up with the coastal provinces. Fourth, among all licensed technologies, utility models are the most popular, and the majority of technology licensing has taken place between Chinese entities in China. Most domestic licensing takes place locally, within-province. Finally, although Chinese firms have on average gradually in-licensed newer technologies, the technologies licensed from foreign sources are by no means state-of-the-art.

These findings have strong implications for policymaking. First, they help policy-makers to address the specific external technology needs of the different regions, industrial sectors, and types of organization. They reveal the gaps between the targets set by current innovation policy for independent technology advancement and the most recent reality. This can allow policies to be adjusted accordingly. For instance, innovation policies can suggest instruments to encourage large stateowned enterprises to in-license more state-of-the-art foreign technologies, diversify technology licensing activities among industries, and promote licensing activities across provinces. For firms, these findings help to identify and match missing technological competencies and to locate potential technology sources in the geographical and technical dimensions.

Our research only reveals the tip of the iceberg. Future research should continue to explore the relationship between firms' external technological knowledge search behaviors (by means of licensing) and their innovation performance. The interplay among the value, type, 
geographical locations, speed to application, and other features of licensed patents, in combination with firmlevel variables, provides plenty of promising directions for future research. Moreover, investigating how the local intellectual property regimes in different regions in China influence the propensity of organizations to license and appropriate external technologies is another interesting potential research area.

\section{Funding}

This work was supported by the National Science Foundation of China (grant no.71302133), Youth Project of Ministry of Education, Humanities and Social Sciences Planning Funding (grant no. 13YJC790154), and the social science fund of the Sino-Danish Centre in 2013.

\section{References}

Altenburg, T., Schmitz, H. and Stamm, A. (2008) 'Breakthrough? China's and India's transition from production to innovation', World Development, 36: 325-44.

Chen, D. and Li-Hua, R. (2011) 'Modes of technological leapfrogging: Five case studies from China', Journal of Engineering and Technology Management, 28: 93-108.
Chen, X. and Sun, C. (2000) 'Technology transfer to China: Alliances of Chinese enterprises with western technology exporters', Technovation, 20: 353-62.

Cummings, J. L. and Teng, B.-S. (2003) 'Transferring R\&D knowledge: The key factors affecting knowledge transfer success', Journal of Engineering and Technology Management, 20: 39-68.

Deng, P. (2009) 'Why do Chinese firms tend to acquire strategic assets in international expansion?', Journal of World Business, 44: $74-84$

Ernst, H. (2003) 'Patent information for strategic technology management', World Patent Information, 25: 233-42.

Grupp, H. and Schmoch, U. (1999) 'Patent statistics in the age of globalization: New legal procedures, new analytical methods, new economic interpretation', Research Policy, 28: 377-96.

Huang, K. (2010) 'China's innovation landscape', Science, 329: 632-3.

Kollmer, H. and Dowling, M. (2004) 'Licensing as a commercialization strategy for new technology-based firms', Research Policy, 33: 1141-51.

Laursen, K., Leone, M. I. and Torrisi, S. (2010) 'Technological exploration through licensing: New insights from the licensee's point of view', Industrial and Corporate Change, 19: 871-97.

Park, W. and Lippoldt, D. C. (2004) 'International licensing and the strengthening of intellectual property rights in developing countries', OECD Trade Policy Working Papers, No. 10. Paris: OECD.

Sun, Y. and Du, D. (2010) 'Determinants of industrial innovation in China: Evidence from its recent economic census', Technovation, 30: 540-50. 